\title{
Prevalence and phylogenetic analysis of honey bee viruses in the Biobío Region of Chile and their association with other honey bee pathogens
}

\author{
Marta Rodríguez ${ }^{1}$, Marisol Vargas ${ }^{1 *}$, Karina Antúnez², Marcos Gerding ${ }^{3}$, Fidel Ovídio Castro ${ }^{4}$, \\ and Nelson Zapata ${ }^{1}$
}

Different episodes of mortalities of honey bee (Apis mellifera L.) colonies have been associated with the presence of honey bee pathogens. Since the Biobío Region has among the highest number of apiaries in Chile, the aim of the present study was to identify viruses in the Region affecting honey bees, evaluate their relation to other pathogens, and conduct a phylogenetic analysis. Pupae and adult bees were collected from 60 apiaries of Apis mellifera L. in the Biobío Region over 2 yr. RNA viruses were detected by reverse transcription PCR (RT-PCR), and Acarapis woodi, Nosema spp., and Varroa destructor via PCR. Three viruses were detected: Acute bee paralysis virus (ABPV), Black queen cell virus (BQCV) and Deformed wing virus (DWV) in $2 \%, 10 \%$, and $42 \%$ of the apiaries, respectively. No statistical correlation was observed between the presence of the different viruses, V.destructor, A. woodi, and the two Nosema species, and the bee development stages. One year after the first sampling, DWV and BQCV were detected mainly in foraging adult bee samples. Three percent of the apiaries were infected with $N$. apis and $18 \%$ with $N$. ceranae, $5 \%$ were positive for $V$. destructor, while $A$. woodi was not detected. PCR products were sequenced and compared to the Genbank database. Chilean sequences of ABPV, BQCV, and DWV showed high percentages of similarity to other isolates in South America.

Key words: Acute bee paralysis virus, Apis mellifera, Black queen cell virus, Deformed wing virus, Nosema ceranae.

\section{INTRODUCTION}

Pollinators are a key component of global biodiversity, providing vital ecosystem services to crops and wild plants (Potts et al., 2010). Klein et al. (2007) found that fruit, vegetable and seed production from 87 of the leading global food crops are dependent on pollinators. The honey bee (Apis mellifera L.) is the most important natural pollinator for a wide variety of crops and flowering plants (Potts et al., 2010).

There are around 500000 commercial hives in Chile, which are distributed from the Antofagasta Region to the Aysén del General Carlos Ibáñez del Campo Region (Laval et al., 2010). Considering just the pollination requirements from October to November, the demand in Central Chile

${ }^{1}$ Universidad de Concepción, Facultad de Agronomía, Av. Vicente Méndez 595, Chillán, Chile.

"Corresponding author (marisolvargas@udec.cl).

${ }^{2}$ Instituto de Investigaciones Biológicas Clemente Estable, Departamento de Microbiología, Avda. Italia 3318, Montevideo, Uruguay.

${ }^{3}$ Centro de Producción de Insectos Benéficos BioBichos Ltda., Variante Cato s/n, Chillán, Chile.

${ }^{4}$ Universidad de Concepción, Facultad de Medicina Veterinaria, Av. Vicente Méndez 595, Chillán, Chile.

Received: 19 July 2013.

Accepted: 4 March 2014.

doi:10.4067/S0718-58392014000200007 ranges from 758312 to 947890 colonies (average of 8-10 colonies ha-1), which is twice the number of existing ones, given that the total area requiring pollinators is close to 177000 ha (Estay, 2012). Moreover, in 2007 the demand for hives for pollination was 1202694 for almond, cherry, European plum, Japanese plum, apple, pear, avocado, kiwi, blueberry, and raspberry production (de la Cuadra, 2010).

However, colonies of A. mellifera are suffering significant losses worldwide. Between 1961 and 2007, honey bee populations in Europe and North America declined by $26 \%$ and $49 \%$, respectively (vanEngelsdorp and Meixner, 2010). Different episodes of mortality and reductions in honey production associated with viral infections have been reported worldwide (Chen et al., 2005; Chen and Siede, 2007; Bacandritsos et al., 2010; Gumusova et al., 2010; Genersch and Aubert, 2010; Ai et al., 2012). In effect, there is increasing concern about the effect of viral infections on honey bee populations, largely due to the potential relation between viral diseases and honey bee mortality (Cox Foster et al., 2007; Maori et al., 2009; Hunter et al., 2010).

Although there is no official information about the mortality of colonies in Chile, beekeepers have observed an increase in the percentage of winter losses in recent years. The symptoms and causes are not clear. Allen and Ball (1996) reported that at least 18 viruses infect $A$. 
mellifera, which can be present in all bee development stages: egg, larva, pupae, and adult (Chen et al., 2006). Among these, seven viruses are the most common: Black queen cell virus (BQCV); Deformed wing virus (DWV); Kashmir bee virus (KBV); Sacbrood bee virus (SBV); Acute bee paralysis virus (ABPV); Chronic bee paralysis virus (CBPV) and Israeli acute paralysis virus (IAPV) (Tentcheva et al., 2004; Yooa et al., 2012) and their complete genome sequences have been reported (Ghosh et al., 1999; Govan et al., 2000; Leat et al., 2000; Chen et al., 2004a; Fujiyuki et al., 2004; Maori et al., 2007).

In South America the presence of honey bee viruses (ABPV, CBPV, BQCV, SBV, and DWV) has been reported in Argentina, Uruguay, and Brazil (Antúnez et al., 2005; 2006; Teixeira et al., 2008; Reynaldi et al., 2010). Rodríguez et al. (2012) made the first report of the presence in Chile of BQCV, SBV, and DWV in apiaries at Curepto, Maule Region. The most prevalent virus in colonies with high levels of mortality was BQCV. According to field observations, the affected hives presented large numbers of dead bees at the hive entrances. As well shiny black alopecic bees were observed dragging themselves on the ground, and queen bees showing similar symptoms and then disappearing from the colonies. In addition, Barriga et al. (2012) detected DWV in two places in the Chilean Metropolitan Region.

Since the Biobío Region has among the highest number of apiaries in the country, a number of samples were collected from colonies from different locations in this region in order to identify viruses affecting the honey bee A. mellifera, and evaluate the presence of other pathogens such as: mites Varroa destructor and Acarapis woodi, and the microsporidia Nosema apis and Nosema ceranae.

\section{MATERIALS AND METHODS}

\section{Samplings from apiaries}

This study was conducted during the springs and summers of 2010 and 2011. The first part (2010) was carried out in 20 districts $\left(36^{\circ} 46^{\prime} 22^{\prime}\right.$ S, $73^{\circ} 3^{\prime} 47^{\prime}$ ' W) of the Biobío Region, in longitudinal strips in the Andean foothills, the coastal area, and the central valley. Three apiaries were randomly selected in each of the 20 district for sampling, making a total of 60 apiary samplings. Three colonies were sampled from each apiary, from which 30 pupae were collected from the honeycombs and 30 foraging bees from the hive entrance (Yue and Genersch, 2005). The pupae or foraging bees from the same apiary formed part of a composite sample that was stored at $-80^{\circ} \mathrm{C}$ until analyzed.

A second sampling was carried out in 2011 only in apiaries where BQCV had been detected from the previous sampling. Larvae, pupae, nurse bees, foragers, young queen larvae (when present), and $V$. destructor mites were collected from three hives from each apiary. Samples were analyzed for the presence of the viruses $N$. apis, N. ceranae, A. woodi, and V. destructor.

\section{RNA and DNA extraction}

Ten bees or 20 mites from each apiary sample were placed in a sterile porcelain mortar and ground in liquid nitrogen. RNA was extracted from $0.171 \mathrm{mg}$ tissue using the SV Total RNA Isolation System Kit (Promega, Madison, Wisconsin, USA), following the manufacturer's protocol. Total RNA was used to detect viruses.

The remaining tissue ( $c a .20 \mathrm{mg}$ ) was processed for DNA extraction using the Wizard $($ SV Genomic DNA Purific (Promega, USA). The DNA was used to detect $N$. apis, N. ceranae, A. woodi, and V. destructor via polymerase chain reaction (PCR).

\section{RT-PCR to detect viruses}

The RNA samples were tested for the presence of four viruses: BQCV, DWV, SBV, and ABPV, through reverse transcription PCR (RT-PCR) using the primers listed in Table 1 .

Reverse transcription of the samples was conducted with M-MLV Reverse Transcriptase (Invitrogen, Foster City, California, USA) following the manufacturer's protocol. The amplifications were performed in a thermal cycler (BIO RAD, My Gene TM Series Peltier Termal Cycler, San Francisco, CA, USA). Obtained cDNA was then used for PCR. The reaction mix contained $0.2 \mathrm{mM}$ of dNTPs, $1 \mu \mathrm{M}$ of each primer, $1 \mathrm{x}$ buffer, $1.5 \mathrm{mM} \mathrm{MgCl}_{2}, 1 \mathrm{U}$ of Taq polymerase (TM Invitrogen, USA) and $1 \mu \mathrm{L}$ of cDNA (undiluted), to a total final volume of $30 \mu \mathrm{L}$. For ABPV, BQCV, and $\mathrm{SBV}$, denaturation and activation of the polymerase were performed at $95{ }^{\circ} \mathrm{C}$ for $2 \mathrm{~min}$, followed by 40 PCR cycles: $30 \mathrm{~s}$ at $95^{\circ} \mathrm{C}, 1 \mathrm{~min}$ at $55^{\circ} \mathrm{C}$, and $2 \mathrm{~min}$ at $68^{\circ} \mathrm{C}$. Reactions were completed by a final elongation step at $68^{\circ} \mathrm{C}$ for $7 \mathrm{~min}$.

Table 1. Primers used for the detection of different bee viruses.

\begin{tabular}{|c|c|c|c|c|c|}
\hline Pathogen & & Primers $\left(5^{\prime} \rightarrow 3^{\prime}\right)$ & Target sequence & $\begin{array}{c}\text { Size } \\
\mathrm{Pb}\end{array}$ & Source \\
\hline \multirow[t]{2}{*}{ ABPV } & $\mathrm{F}$ & TTATGTGTCCAGAGACTGTATCCA & \multirow[t]{2}{*}{ Capsid protein gene } & \multirow[t]{2}{*}{900} & \multirow[t]{2}{*}{ Benjeddou et al., 2001} \\
\hline & $\mathrm{R}$ & GCTCCTATTGCTCGGTTTTTCGGT & & & \\
\hline \multirow[t]{2}{*}{ BQCV } & $\mathrm{F}$ & TGGTCAGCTCCCACTACCTTAAAC & \multirow[t]{2}{*}{ Nonstructural polyprotein (orf1) structural polyprotein (orf2) gene } & \multirow[t]{2}{*}{700} & \multirow[t]{2}{*}{ Benjeddou et al., 2001} \\
\hline & $\mathrm{R}$ & GCAACAAGAAGAAACGTAAACCAG & & & \\
\hline \multirow[t]{2}{*}{ DWV } & $\mathrm{F}$ & TTTGCAAGATGCTGTATGTGG & \multirow[t]{2}{*}{ Polyprotein gene } & \multirow[t]{2}{*}{395} & \multirow[t]{2}{*}{ Tentcheva et al., 2004} \\
\hline & $\mathrm{R}$ & GTCGTGCAGCTCGATAGGAT & & & \\
\hline \multirow[t]{2}{*}{ SBV } & $\mathrm{F}$ & GCTGAGGTAGGATCTTTGCGT & \multirow[t]{2}{*}{ Helicase, protease and polymerase gene } & \multirow[t]{2}{*}{824} & \multirow[t]{2}{*}{ Chen et al., 2004a; 2004b } \\
\hline & $\mathrm{R}$ & TCATCATCTTCACCATCCGA & & & \\
\hline
\end{tabular}

ABPV: Acute bee paralysis virus; BQCV: Black queen cell virus; DWV: Deformed wing virus; SBV: Sacbrood bee virus.

F: Forward; R: Reverse. 
For DWV, denaturation and activation of the polymerase was performed at $95{ }^{\circ} \mathrm{C}$ for $2 \mathrm{~min}$ followed by 30 PCR cycles: $30 \mathrm{~s}$ at $95^{\circ} \mathrm{C}, 1 \mathrm{~min}$ at $52^{\circ} \mathrm{C}$, and $1 \mathrm{~min}$ at $72{ }^{\circ} \mathrm{C}$; and a final elongation step at $72^{\circ} \mathrm{C}$ for $7 \mathrm{~min}$.

Positive controls (cDNA) were provided by the Department of Microbiology of the Institute for Biological Research Clemente Estable, Montevideo, Uruguay.

\section{PCR to detect Nosema sp., A. woodi and V. destructor}

The PCR reaction mix to detection $N$. apis and $N$. ceranae followed the protocol described by Martín-Hernández et al. (2007). A positive control was included with all PCRs, which consisted of DNA from $N$. ceranae and $N$. apis obtained from the Regional Apicultural Center, Marchamalo, Spain.

The PCR reactions for $A$. woodi were according to Evans et al. (2007). A positive control sample of DNA extracted from bees infested with $A$. woodi was provided by the Asociación Gremial de Apicultores Biobío Region (BIOMIEL A.G.) and was included with all the PCRs. The positive control was analyzed according to the procedure of the World Organization for Animal Health (OIE, 2008). The PCR reaction to detect $V$. destructor was performed according to Evans and Lopez (2002). A positive control sample of DNA extracted from bees infested with varroa was included with all PCR reactions. The primers used to $\operatorname{detect} A$. woodi and $V$. destructor were synthesized by Invitrogen according to Evans et al. (2007) and Evans and Lopez (2002), respectively.

\section{Analysis of amplified products}

The PCR and RT-PCR products were analyzed by electrophoresis in a $1 \%$ Tris-acetate-EDTA buffer agarose gel and stained with ethidium bromide. Amplified products were photographed in a UV light transilluminator (Vilber Lourmat Modelo TFX-20.M, EEC) and their length was determined with a 100-bp DNA ladder (Invitrogen, USA).

\section{Nucleotide sequencing and phylogenetic analysis}

ABPV,BQCV, and DWV amplicons were sequenced using the primer pairs described above (Table 1) by Macrogen (Seoul, Korea). The nucleotide sequences were identified using the Basic Local Alignment Search Tool (BLAST) at the National Center for Biotechnology Information (NCBI, Bethesda, MD, USA). Multiple nucleotide alignment was carried with the program BioEdit version 7.0.0 and using published ABPV, BQCV, and DWV sequences as references (Hall, 1999). A phylogenetic tree was constructed with Mega 5 software (Tamura et al., 2011) using the neighbor-joining (NJ) method with a bootstrap value of 1000 to assess robustness.

\section{Statistical analysis}

A statistical analysis of frequency for each virus was performed to evaluate correlations among the presence of different viruses, V. destructor, A. woodi, N. apis, and $N$. ceranae, and different bee developmental stages. Each data set was summarized in contingency tables and analyzed using the Pearson chi square test.

\section{RESULTS}

\section{Virus detection}

Of the 60 apiaries sampled in 2010, $2 \%$ was positive for ABPV, $10 \%$ for BQCV, and $42 \%$ for DWV. SBV was not detected (Table 2). Only $7 \%$ of the apiaries were coinfected by BQCV and DWV. There was no co-infection between ABPV and other viruses. DWV and BQCV were detected in both adult bees and pupae while ABPV was only detected in adult bees.

Three percent of tested apiaries were positive for $N$. apis and $18 \%$ for $N$. ceranae. Five of the positive samples for $N$. ceranae were co-infected with DWV (8\% of the total), and one of these also presented BQCV ( $2 \%$ of the total). Only $5 \%$ of the apiaries were positive for $V$. destructor, two samples had co-infection with DWV. Acarapis woodi was not detected. No statistical correlation was found between the presence of the different viruses, $V$. destructor, A. woodi, and the two Nosema species and the bee developmental stage $(\mathrm{p}=0.124)$.

To verify the identity of detected amplicons, PCR products were sequenced and compared to the Genbank database. The sequences obtained shared a high percentage of similarity to published sequences for ABPV (98\% sequence similarity to AY763414.1), BQCV (98\% to EF517520.1), DWV (100\% to HM067437.1), $N$. apis (100\% to JQ639306.1), N. ceranae (100\% to JQ639307.1), V. destructor (100\% to AJ493124.2), and A. woodi (100\% to GO916565.1). BQCV was detected in six apiaries in the first year (2010), but in the second year (2011) it was possible to sample only four of these apiaries, in three of which BQCV was found. It was detected mainly in foraging bees, although in one case it was also found in nurse bees and queen larvae. DWV was detected in all the samples and was present in different bee developmental stages. All the analyzed samples of $V$. destructor were infected by DWV.

Nosema ceranae-positive samples were found in two apiaries, in one of which microsporidia was detected in larvae, pupae, nurse bees, foragers, queen larvae, and $V$. destructor, while in the other apiary $N$. ceranae was only detected in foraging bees. Nosema apis was only detected in the samples from one apiary, in pupae and forager bee samples. Samples from this apiary were negative to the other pathogens. ABPV, SBV, and A. woodi were not detected in any of the sampled apiaries (Table 3).

\section{Nucleotide sequencing and phylogenetic analysis}

Phylogenetic analysis was carried out by sequencing fragments 905-bp of the gene coding for a capsid protein of ABPV (KF011920), 300-bp of a gene coding a structural protein of BQVC (KF011921), and 395-bp 
Table 2. Detection of ABPV, SBV, DWV, BQCV, Nosema apis, N. ceranae, Acarapis woodi, and Varroa destructor in apiaries in different locations in the Biobío Region, during the spring-summer of 2010.

\begin{tabular}{|c|c|c|c|c|c|c|c|c|c|c|c|}
\hline $\begin{array}{l}\text { Geographic } \\
\text { areas }\end{array}$ & Location & $\begin{array}{l}\text { Geographic } \\
\text { coordinates }\end{array}$ & Stage & ABPV & BQCV & DWV & SBV & N. apis & N. ceranae & $\begin{array}{c}A . \\
\text { woodi }\end{array}$ & $\begin{array}{c}V . \\
\text { destructor }\end{array}$ \\
\hline \multirow{16}{*}{ Coastal area } & Cobquecura & S $36^{\circ} 09^{\prime}$ & Pupal & -- &.- & +++ & - - - & -- & -+- & &.- \\
\hline & & W $72^{\circ} 48^{\prime}$ & Adult & $\ldots$ & $\cdots$ & +++ & -- & $\ldots$ & $-\ldots$ & $\ldots$ & $\cdots$ \\
\hline & Coelemu & S $36^{\circ} 25^{\prime}$ & Pupal & $\ldots$ & $\ldots$ & -+ & $\ldots$ & $\ldots$ & $\ldots$ & & $\ldots$ \\
\hline & & W 72³9' & Adult & $-\cdots$ & $-\cdots$ & -- & -- & -- & $\cdots$ & $-\cdots$ & $-\cdots$ \\
\hline & Tomé & S $36^{\circ} 36^{\prime}$ & Pupal &.- & $\ldots$ &.- & $-\ldots$ & $\ldots$ &.- & &.- \\
\hline & & W $72^{\circ} 49^{\prime}$ & Adult & - - & -- & - - - & -- & -+- & $\ldots$ & -- & -- \\
\hline & Penco & S $36^{\circ} 44^{\prime}$ & Pupal & $\ldots$ & - - - & ++- & $\ldots$ & $\ldots$ & ++- & & $\ldots$ \\
\hline & & W $72^{\circ} 57^{\prime}$ & Adult & -- & -- & ++- & -- & $\cdots$ & ++- & -- & $\cdots$ \\
\hline & Lebu & S $37^{\circ} 36^{\prime}$ & Pupal &.- &.- & ++- &.- &.- & $-\ldots$ & & $\ldots$ \\
\hline & & W $73^{\circ} 32^{\prime}$ & Adult & -- & -+- & -+- & -- & $-\cdots$ & -+- & $-\cdots$ & -- \\
\hline & Cañete & S $37^{\circ} 47^{\prime}$ & Pupal & $-\ldots$ & -- & ++- & -- & $-\ldots$ & -+- & & $-\ldots$ \\
\hline & & $\mathrm{W} 73^{\circ} 23^{\prime}$ & Adult & -- & -- & ++- & -- & $\cdots$ & -+- & $-\cdots$ & $\cdots$ \\
\hline & Contulmo & S $38^{\circ} 00^{\prime}$ & Pupal &.- & -- & -+- & $\ldots$ & $\ldots$ & -- & & -- \\
\hline & & W $73^{\circ} 13^{\prime}$ & Adult & -- & $-\ldots$ & $-\ldots$ & -- & -+- & -++ & -- & -- \\
\hline & Concepción & S 375' & Pupal &.- &.- & $\ldots$ &.- &.- &.- & &.- \\
\hline & & W $73^{\circ} 14^{\prime}$ & Adult & $\ldots$ & -- & $\cdots$ & $\ldots$ & $\ldots$ & $\cdots$ & $\ldots$ & -- \\
\hline \multirow{12}{*}{ Central valley } & San Carlos & S $36^{\circ} 26^{\prime}$ & Pupal & $\ldots$ & -- & $-\cdots$ & $\ldots$ & $-\cdots$ & -- & & $\ldots$ \\
\hline & & W 71º $58^{\prime}$ & Adult & -- & - - - & - . & $-\cdots$ & -- & -- & --- & - - - \\
\hline & Bulnes & S $36^{\circ} 44^{\prime}$ & Pupal & $\ldots$ &.- & ++- & $\ldots$ & - - - & $\ldots$ & & -+ \\
\hline & & W $72^{\circ} 18^{\prime}$ & Adult & - - & -- & -++ & $-\cdots$ & --- & -- & -- & - - - \\
\hline & Quillón & S $36^{\circ} 29^{\prime}$ & Pupal & $\ldots$ & -- & $\ldots$ &.- & -- & -+- & & $\ldots$ \\
\hline & & W $72^{\circ} 17^{\prime}$ & Adult & -- & -+- & -- & $\cdots$ & $-\cdots$ & +-+ & -- & $-\cdots$ \\
\hline & Coihueco & S $36^{\circ} 35^{\prime}$ & Pupal & -- & -+- & -+- & $\cdots$ & -- & -- & & -- \\
\hline & & $\mathrm{W} 72^{\circ} 05^{\prime}$ & Adult & -- & - - - & -+- & $\cdots$ & $-\ldots$ & $-\cdots$ & $-\cdots$ & -- \\
\hline & Chillán Viejo & S $36^{\circ} 36^{\prime}$ & Pupal & -- & +- & -+- & $-\ldots$ & $-\ldots$ & $-\ldots$ & & $-{ }_{-}$ \\
\hline & & W $72^{\circ} 06^{\prime}$ & Adult & -- & - - - & -- & - - & $-\cdots$ & -- & $-\cdots$ & $-\cdots$ \\
\hline & Chillán & S $36^{\circ} 34^{\prime}$ & Pupal &.- &.- & $-\cdots$ & $\ldots$ & $\ldots$ & $-\ldots$ & & $\ldots$ \\
\hline & & $\mathrm{W} 73^{\circ} 03^{\prime}$ & Adult & -- & $-\cdots$ & -- & -- & $-\cdots$ & -- & -- & -- \\
\hline \multirow{12}{*}{ Andean range } & San Fabián de Alico & S $36^{\circ} 35^{\prime}$ & Pupal & $\cdots$ & -- & -+- & $-\cdots$ & $-\ldots$ & -- & & -- \\
\hline & & W 71³0' & Adult & $-\cdots$ & $-\cdots$ & -- & -- & $-\cdots$ & --- & -- & -- \\
\hline & El Carmen & S $36^{\circ} 46^{\prime}$ & Pupal & $\ldots$ & $-\ldots$ & $-\ldots$ & -- & $-\ldots$ & -- & & - \\
\hline & & W $71^{\circ} 30^{\prime}$ & Adult & -- & -- & -- & -- & $-\cdots$ & $\cdots$ & $\ldots$ & -- \\
\hline & Pinto & S $36^{\circ} 46^{\prime}$ & Pupal &.- &.- & -++ & $\ldots$ & $\ldots$ & $\ldots$ & & - \\
\hline & & W $71^{\circ} 49^{\prime}$ & Adult & -+- & +-- & -+- & -- & $-\cdots$ & $-\cdots$ & $-\cdots$ & -+- \\
\hline & Alto Bío Bío & S 373' & Pupal & $\ldots$ & $-\cdots$ &.-- & -- & $\ldots$ &.-- & & $\ldots$ \\
\hline & & W $71^{\circ} 44^{\prime}$ & Adult & $\cdots$ & $\cdots$ & -+- & -- & $\cdots$ & $\cdots$ & $-\cdots$ & -- \\
\hline & Quilaco & S $37^{\circ} 38^{\prime}$ & Pupal & $\ldots$ & -- & -- & -- & $\ldots$ & $\ldots$ & & $\ldots$ \\
\hline & & W $71^{\circ} 43^{\prime}$ & Adult & $\cdots$ & - - & +++ & -- & $\cdots$ & -- & $-\cdots$ & -- \\
\hline & Santa Bárbara & S $37^{\circ} 36^{\prime}$ & Pupal &.- & -+ & ++- & -- & $\ldots$ & $-\ldots$ & &.- \\
\hline & & W $71^{\circ} 47^{\prime}$ & Adult &.- & -+- & -+- & $\ldots$ & $\ldots$ & -- & $\ldots$ & $-\ldots$ \\
\hline
\end{tabular}

+: Positive; -: Negative.

ABPV: Acute bee paralysis virus; BQCV: Black queen cell virus; DWV: Deformed wing virus; SBV: Sacbrood bee virus .

of a gene coding polyprotein of DWV (KC175443.1 and ID1606171), to describe the probable genetic relationship between Chilean viruses and those published in Genbank. In most cases, bootstrap support was high (> 70\%), indicating that clusters were statistically valid.

The phylogenetic trees based on protein coding sequences are shown in Figures 1, 2, and 3, for ABPV,
BQCV, and DWV, respectively. The ABPV isolates originating from Hungary, Poland, Germany, and Austria are clustered in one branch and separated from the South Africa and US isolates, although they share the same origin. The sequences from Brazil, Uruguay, and Chile, clustered in a branch that diverged from the cluster of European, South Africa and US isolates (Figure 1). The 
Table 3. Detection of ABPV, SBV, DWV, BQCV, Nosema apis, $N$. ceranae, Acarapis woodi and Varroa destructor, in apiaries in different locations in the Biobío Region, in the spring of 2011.

\begin{tabular}{|c|c|c|c|c|c|c|c|c|c|}
\hline $\begin{array}{l}\text { Geographic } \\
\text { areas }\end{array}$ & Location & $\begin{array}{l}\text { Geographic } \\
\text { coordinates }\end{array}$ & ABPV & BQCV & DWV & SBV & N. apis & N. ceranae & A. woodi \\
\hline \multirow{6}{*}{ Lebu } & \multirow{6}{*}{$\begin{array}{l}\text { S } 37^{\circ} 36^{\prime} \\
\text { W } 73^{\circ} 32^{\prime}\end{array}$} & Larvae & - & - & + & - & - & + & \multirow{6}{*}{-} \\
\hline & & Pupae & - & - & - & - & - & + & \\
\hline & & Nurse bees & - & + & + & - & - & + & \\
\hline & & Forager bees & - & + & + & - & - & + & \\
\hline & & Queen larvae & - & + & + & - & - & + & \\
\hline & & V. destructor & - & - & + & - & - & + & \\
\hline \multirow{6}{*}{ Santa Bárbara } & \multirow{6}{*}{$\begin{array}{l}\text { S } 37^{\circ} 36^{\prime} \\
\text { W } 71^{\circ} 47^{\prime}\end{array}$} & Larvae & - & - & + & - & - & - & \multirow{6}{*}{-} \\
\hline & & Pupae & - & - & + & - & + & - & \\
\hline & & Nurse bees & - & - & + & - & - & - & \\
\hline & & Forager bees & - & - & + & - & + & - & \\
\hline & & Queen larvae* & & & & & & & \\
\hline & & V. destructor* & & & & & & & \\
\hline \multirow{6}{*}{ Chillán Viejo } & \multirow{6}{*}{$\begin{array}{l}\text { S } 36^{\circ} 36^{\prime} \\
\text { W } 72^{\circ} 06^{\prime}\end{array}$} & Larvae & - & - & - & - & - & - & \multirow{6}{*}{-} \\
\hline & & Pupae & - & - & - & - & - & - & \\
\hline & & Nurse bees & - & - & - & - & - & - & \\
\hline & & Forager bees & - & + & - & - & - & + & \\
\hline & & Queen larvae* & & & & & & & \\
\hline & & V. destructor & - & - & + & - & - & - & \\
\hline \multirow{6}{*}{ El Carmen } & \multirow{6}{*}{$\begin{array}{l}\text { S } 36^{\circ} 46^{\prime} \\
\text { W } 71^{\circ} 30^{\prime}\end{array}$} & Larvae & - & - & & - & - & - & \multirow{6}{*}{-} \\
\hline & & Pupae & - & - & + & - & - & - & \\
\hline & & Nurse bees & - & - & + & - & - & - & \\
\hline & & Forager bees & - & + & + & - & - & - & \\
\hline & & Queen larvae* & & & & & & & \\
\hline & & V. destructor & - & - & + & - & - & - & \\
\hline
\end{tabular}

+: Positive; -: Negative; *: not collected.

ABPV: Acute bee paralysis virus; BQCV: Black queen cell virus; DWV: Deformed wing virus; SBV: Sacbrood bee virus.

BQCV sequences from South Korea, the USA, and Uruguay are clustered in one branch, while sequences from Chile and Brazil form a distinct branch from other isolates showing a high divergence from the first group (Figure 2).

Chilean sequences of DWV are closely related to isolates from the UK, the USA, Spain, Japan, and Uruguay, forming a sole cluster, with at least two sub-clusters, one with three UK isolates and closely related isolates from the USA, Italy, and Spain. The other sub-cluster consists of Chilean, Uruguayan, and UK isolates, while isolates from Israel and the Netherlands form a distinct branch separated from other isolates.

\section{DISCUSSION}

The Biobío Region has the largest number of beehives in Chile, with about 69597 hives, which is $15 \%$ of the hives in the country (Laval et al., 2010). In the present work, we analyzed 180 hives located in 60 apiaries, equivalent to $0.26 \%$ of the hives in the region. The first sample was collected in spring-summer 2010 at different locations and geographic areas with distinct rainfall and thermal conditions. According to the beekeepers, the main problem is $V$. destructor, which in most cases is controlled in autumn using acaricide Amitraz $\left(N, N^{\prime}\right.$ [(methylimino)dimethylidyne]di-2,4-xylidine). In some cases, beekeepers reported the loss of part of the bee population, but no defined symptoms were detected.

From the collected samples three viruses were detected: DWV, BQCV, and ABPV. High numbers of samples infected with DWV were detected $(42 \%$ of apiaries), even when the number of positive samples to $V$. destructor, the main vector for this virus (de Miranda and Genersch, 2010), was low. The infestation value of $V$. destructor is probably underestimated, given that the analysis was performed on a small number of bees (30). As well, that spring was not the best season to perform the analysis, since colonies had been treated with acaricide in autumn. As well, obtained results could indicate that there are other transmission pathways of the viruses, such as horizontal transmission through contaminated food (pollen and honey) or vertical transmission from mother to brood (Chen et al., 2005; 2006).

The Chilean DWV sequence found in this study was highly similar to sequences from the USA, Spain, and Japan. Barriga et al. (2012) detected DWV in two sites in the Metropolitan Region of Chile and sequenced the complete genome of the virus. The authors indicated that the Chilean DWV strain is closely related to strains in England and Italy. The two studies agree that the virus has affected apiaries in particular sites and suggest expanding nationwide surveys. Phylogenetic studies by Berenyi et al. (2007) with DWV sequences of different geographic origins (Germany, Austria, Poland, Hungary, Slovenia, Nepal, Sri Lanka, the United Arab Emirates, Canada, and New Zealand) showed that certain regions of the DWV genome can be highly conserved, independent of the geographic origin of the bee sample, finding high genetic similarity and little genetic distance between them.

The most common and prevalent viruses affecting $A$. mellifera in the world are DWV and BQCV (Zhang et al., 2012). Earlier reports detected $82 \%$ of BQCV infection 


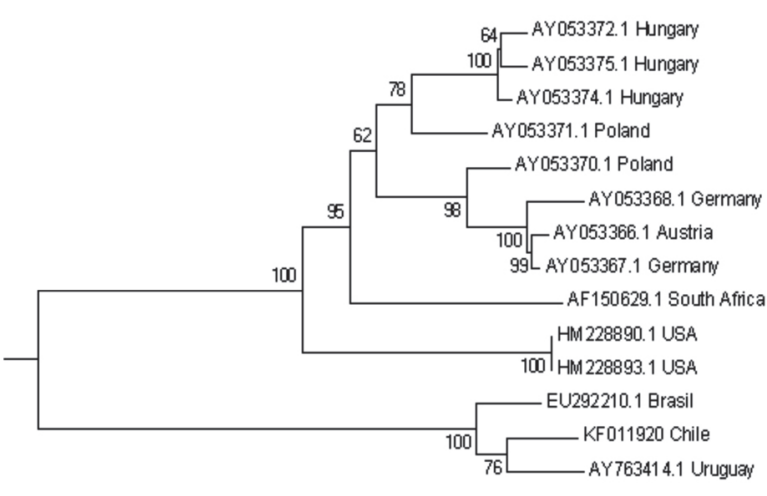

10

Figure 1. Neighbor-joining phylogenetic tree based on a fragment of 905-bp of the gene that encodes for a structural protein of the acute bee paralysis virus (ABPV). Bootstrap values are shown above the branches.

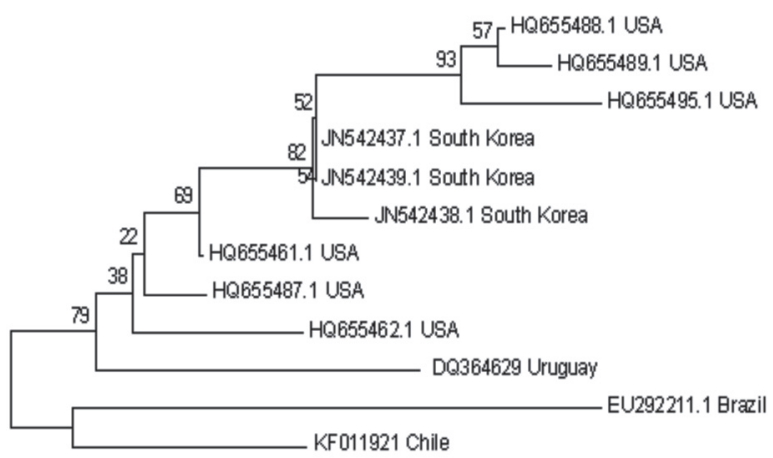

$\longmapsto 1$

Figure 2. Neighbor-joining phylogenetic tree based on a fragment of 300-bp that encodes for a non-structural polyprotein of the Black queen cell virus (BQCV). Bootstrap values are shown above the branches.

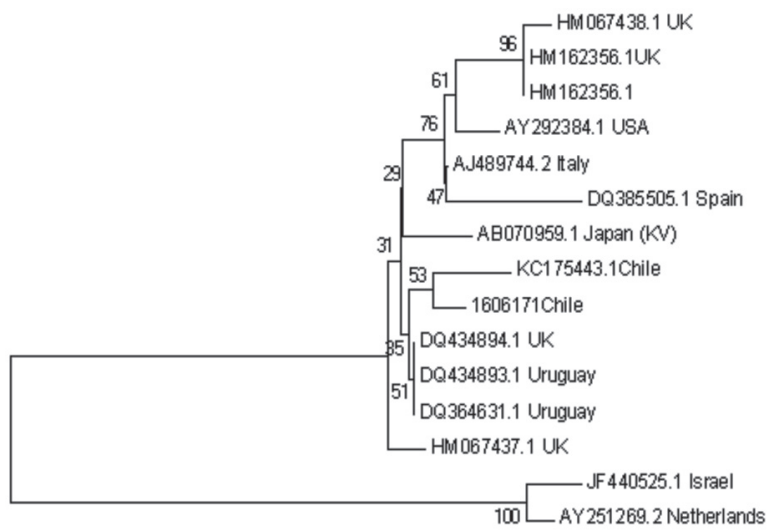

Figure 3. Neighbor-joining phylogenetic tree based on a fragment of 395-bp of the gene that encodes for a polyprotein of Deformed wing virus (DWV). Bootstrap values are shown above the branches. in colonies from apiaries with high bee mortality rates at Curepto, Maule Region, Chile, located approximately $300 \mathrm{~km}$ from the studied area (Rodríguez et al., 2012). In contrast, only $10 \%$ of samples in this work were positive for BQCV. The Chilean sequence of this virus was genetically distant to available sequences from other countries. When aligning the sequence to Brazilian and Uruguayan sequences, $96 \%$ identities were found. The phylogenetic proximity to the Brazilian sequence may explain the origin of this virus in Chile, although we do not know of any commercial exchange of biological material with this country.

The present work makes the first report of the presence of ABPV in Chile, although its prevalence in the analyzed samples is low $(2 \%)$. This virus has been reported in other South America countries, such as Argentina, Brazil, and Uruguay (Antúnez et al., 2005; Teixeira et al., 2008; Reynaldi et al., 2010). The Chilean isolate nucleotide sequence had a high percentage of similarity (in the Capsid protein gene) to Brazilian and Uruguayan isolates ( $97 \%$ and $93 \%$, respectively) (there is no published data on the ABPV sequence from Argentina), confirming that the ABPV capsid polyprotein gene is a relatively conserved genomic region (Bakonyi et al., 2002). The proximity of Brazil and Uruguay to Chile suggests they are origin of the virus in Chile.

Nosema ceranae has also been detected in the present work, in $18 \%$ of analyzed apiaries. Although it has been described as an adult bee parasite (Higes et al., 2008; Forsgren and Fries, 2010), this microsporidia was also found in pupae, probably due to spore contamination from nurse bees, which have been described as carriers of this parasite (Meana et al., 2010) or through feeding with contaminated pollen (Higes et al., 2008). Other studies carried out in the spring of 2010 and summer of 2011 in the same region revealed that $N$. ceranae is widely distributed in the region (Martínez et al., 2012). However, in the present study we only detected $N$. ceranae in $18 \%$ of the analyzed apiaries. A possible reason is that the authors of the other studies sampled a larger number of beehives $(\mathrm{N}=240)$ in a larger number of communities ( $\mathrm{N}$ $=26$ ) in the Biobío Region.

One year after the first collection, BQCV prevailed in the hives. This virus was detected mainly in forager bee samples and at one apiary among queen larvae and nurse bees. BQCV was originally detected among dead queen larvae and pupae, and different reports show that the disease is associated with $N$. apis infestation (Bailey et al., 1983; Allen and Ball, 1996). However, co-infection between BQCV and $N$. apis was not detected in the apiaries studied in this work. We detected $N$. ceranae in co-infection with BQCV and DWV in only one of the apiaries. Numerous viral diseases have been reported to be associated with V. destructor infestation (Ball and Allen, 1988; Allen and Ball, 1996; Martin et al., 1998; Tentcheva et al., 2004). In this work we analyzed the presence of 
DWV, BQCV, SBV, and ABPV in V. destructor, but we only detected DWV in mite samples. We also detected the presence of $N$. ceranae in $V$. destructor. It is possible that the mite transports $N$. ceranae spores in its body. However, with only one positive sample, more analysis is needed to prove this hypothesis.

There are several reports globally on viral bee infections and numerous studies related to their pathogenesis, genetic variability, and phylogeny. However, knowledge about viral bee pathogens in Chile is still limited and incipient. Beekeeping in the studied area focuses not only on honey production, but also pollination, and queen bee and nucleus colony production. Therefore there is permanent movement of biological material, which can accelerate the spread and transmission of diseases.

This study arose from the need for information about the health of beehives and the presence of unreported pathogens, as well as the need to develop appropriate detection techniques. It is expected that the information generated will be useful not only in explaining bee mortality when there are no visible symptoms or pathogens, but also in developing new techniques to manage bee health in Chilean apiaries.

\section{CONCLUSIONS}

Three viruses were detected in the Biobío Region, Chile: Acute bee paralysis virus, Black queen cell virus, and Deformed wing virus in $2 \%, 10 \%$, and $42 \%$ of the apiaries, respectively. Three percent of the apiaries were infected with Nosema apis and $18 \%$ with N.ceranae, only $5 \%$ were positive for Varroa destructor, and Acarapis woodi was not detected. No statistical correlation was found between the presence of different viruses, V. destructor, A. woodi, and the two Nosema species, and the bee developmental stage.

PCR products were sequenced and compared to the Genbank database. Chilean sequences of ABPV, BQCV, and DWV showed high percentage of sequence similarity to other isolates in South America.

\section{ACKNOWLEDGEMENTS}

We thank Dra. Macarena Gerding of the University of Concepción and Mario Zapata, MSc from Servicio Agrícola y Ganadero (SAG) for their help in the phylogenetic analysis. This work was supported by grants from INNOVA BIO BIO and DIUC Universidad de Concepción nr 211.122.024-1.0.

\section{LITERATURE CITED}

Ai, H., X. Yan, and R. Han. 2012. Occurrence and prevalence of seven bee viruses in Apis mellifera and Apis cerana apiaries in China. Journal Invertebrate Pathology 109:160-164.

Allen, M.F., and B. Ball. 1996. The incidence and World distribution of honey bee viruses. Bee World 77:141-162.
Antúnez, K., B. D’Alessandro, E. Corbella, G. Ramallo, and P. Zunino. 2006. Honeybee viruses in Uruguay. Journal Invertebrate Pathology 93:67-70.

Antúnez, K., B. D’Alessandro, P. Zunino, and E. Corbella. 2005. Detection of Chronic bee paralysis virus and Acute bee paralysis virus in Uruguayan honeybees. Journal Invertebrate Pathology 90:69-72

Bacandritsos, N.,A. Granato, G. Budge, I. Papanastasiou, E. Roinioti, M. Caldon, et al. 2010. Sudden deaths and colony population decline in Greek honey bee colonies. Journal of Invertebrate Pathology 105:335-340.

Bailey, L., B.V. Ball, and J.N. Perry. 1983. Association of viruses with two protozoal pathogens of the honey bee. Annals of Applied Biology 103:13-20.

Bakonyi, T., E. Grabensteiner, J. Kolodziejek, M. Rusvai, G. Topolska, W. Ritter, et al. 2002. Phylogenetic analysis of acute bee paralysis virus strains. Applied and Environmental Microbiology 68:6446-6450

Ball, B.V., and M.F. Allen. 1988. The prevalence of pathogens in honeybee (Apis mellifera) colonies infested with the parasitic mite Varroa jacobsoni. Annals of Applied Biology 113:237-244.

Barriga, G., N. Cifuentes, P. Rivera, M. Gutierrez, A. Shmaryahu, P. Valenzuela, et al. 2012. First detection and complete genome sequence of Deformed wing virus in Chilean honeybees. Virus Genes 45:606-609.

Benjeddou, M., N. Leat, M. Allsopp, and S. Davison. 2001. Detection of acute bee paralysis virus and black queen cell virus from honey bees by reverse transcriptase PCR. Applied and Environmental Microbiology 67:2384-2387.

Berenyi, O., T. Bakonyi, I. Derakhshifar, H. Koglberger, G. Topolska, W. Ritter, et al. 2007. Phylogenetic analysis of deformed wing virus genotypes from diverse geographic origins indicates recent global distribution of the virus. Applied and Environmental Microbiology 73:3605-3611.

Cox-Foster, D.L., S. Conlan, E.C. Holmes, G. Palacios, J.D. Evans, N.A. Moran, et al. 2007. A metagenomic survey of microbes in honey bee colony collapse disorder. Science 318(5848):283-287.

Chen, Y., J. Evans, and M. Feldlaufer. 2006. Horizontal and vertical transmission of viruses in the honey bee, Apis mellifera. Journal of Invertebrate Pathology 92:152-159.

Chen, Y., J.S. Pettis, and M.F. Feldlaufer. 2005. Detection of multiple viruses in queen of the honey bee Apis mellifera L. Journal of Invertebrate Pathology 90:118-121.

Chen, Y.P., and R. Siede. 2007. Honey bee viruses. Advances in Virus Research 70:33-80.

Chen, Y.P., I.B. Smith, A.M. Collins, J.S. Pettis, and M.F. Feldlaufer. 2004b. Detection of deformed wing virus infection in honey bees, Apis mellifera L., in the United States. American Bee Journal 144:557-559.

Chen, Y.P., Y. Zhao, J. Hammond, H.-T. Hsu, J.D. Evans, and M.F. Feldlaufer. 2004a. Multiple virus infections in the honey bee and genome divergence of honey bee viruses. Journal of Invertebrate Pathology 87:84-93.

de la Cuadra, S. 2010. Polinización de cultivos agrícolas: Una mirada actualizada. Actualidad Apícola N² 2. p. 2-5. Consorcio Apícola, Valdivia, Chile.

de Miranda, J.R., and E. Genersch. 2010. Deformed wing virus. Journal of Invertebrate Pathology 103:S48-S61.

Estay, P. (ed.) 2012. Abejas Apis mellifera (Hymenoptera: Apidae): polinización según especie objetivo. Boletín INIA No 235.163 p. Instituto de Investigaciones Agropecuarias INIA, Centro Regional de Investigación La Platina, Santiago, Chile.

Evans, J., and D. Lopez. 2002. Complete mitochondrial DNA sequence of the important honey bee pest, Varroa destructor (Acari: Varroidae). Experimental and Applied Acarology 27:69-78.

Evans, J., J. Pettis, and I.B. Smith. 2007. A diagnostic genetic test for the honey bee tracheal mite, Acarapis woodi. Journal of Apicultural Research 46(3):95-197.

Forsgren, E., and I. Fries. 2010. Comparative virulence of Nosema ceranae and Nosema apis in individual European honey bees. Veterinary Parasitology 170:212-217. 
Fujiyuki, T., H. Takeuchi, M. Ono, S. Ohka, T. Sasaki, A. Nomoto, et al. 2004. Novel insect picorna-like virus identified in the brains of aggressive worker honeybees. Journal of Virology 78:1093-1100.

Genersch, E., and M. Aubert. 2010. Emerging and re-emerging viruses of the honey bee (Apis mellifera L.) Veterinary Research 41:54.

Ghosh, R.C., B.V. Ball, M.M. Willcocks, and M.J. Carter. 1999. The nucleotide sequence of sacbrood virus of the honey bee: An insect picornavirus. Journal of General Virology 80:1541-1549.

Govan, V.A., N. Leat, M. Allsopp, and S. Davison. 2000. Analysis of the complete genome sequence of acute bee paralysis virus shows that it belongs to the novel group of insect-infecting RNA viruses. Virology 277:457-463.

Gumusova, O., H. Albayrak, M. Kurt, and Z. Yazici. 2010. Prevalence of three honey bee viruses in Turkey. Veterinarski Arhiv 80:779-785.

Hall, T.A. 1999. BioEdit: a user-friendly biological sequence alignment editor and analysis program for Windows 95/98/NT. Nucleic Acids Symposium Series 41:95-98.

Higes, M., R. Martín-Hernandez, E. Garrido-Bailón, P. GarcíaPalencia, and A. Meana. 2008. Detection of infective Nosema ceranae (Microsporidia) spores in corbicular pollen of forager honeybees. Journal of Invertebrate Pathology 97:76-78.

Hunter, W., J. Ellis, D. vanEngelsdorp, J. Hayes, D. Westervelt, E. Glick, et al. 2010. Large-scale field application of RNAi technology. PLoS Pathogens 6(12):e1001160. doi:10.1371/ journal.ppat. 1001160

Klein, A.M., B.E. Vaissière, J.H. Cane, I. Steffan-Dewenter, S.A. Cunnigham, C. Kremen, et al. 2007. Importance of pollinators in changing landscapes for world crops. Proceedings of the Royal Society Biological Sciences 274:303-313.

Laval, E., P. Eguillor, y D. Barrera. 2010. Sector apícola chileno: localización del sector y cambios intercensales (1997-2007) bajo una perspectiva de género. Oficina de Estudios y Políticas Agrarias (ODEPA), Santiago, Chile. Available at http://www.odepa.gob.cl/ odepaweb/publicaciones/doc/2290.pdf (accessed March 2013).

Leat, N., B. Ball, V. Govan, and S. Davison. 2000. Analysis of the complete genome sequence of black queen-cell virus, a picornalike virus of honey bees. Journal of General Virology 81:21112119.

Maori, E., S. Lavi, R. Mozes-Koch, Y. Gantman, Y. Peretz, O. Edelbaum, et al. 2007. Isolation and characterization of IAPV, a dicistrovirus affecting honeybees in Israel: evidence for diversity due to intra- and inter-species recombination. Journal of General Virology 88:3428-3438.

Maori, E., N. Paldi, S. Shafir, H. Kalev, E. Tsur, E. Glick, et al. 2009. IAPV, a bee-affecting virus associated with Colony Collapse Disorder can be silenced by dsRNA ingestion. Insect Molecular Biology 18:55-60.

Martin, S.J., A. Hogarth, J. van Breda, and J. Perrett. 1998. A scientific note on Varroa jacobsoni Oudemans and the collapse of Apis mellifera colonies in the United Kingdom. Apidology 29:369-370
Martín-Hernández, R., A. Meana, L. Prieto, A. Martinez Salvador, E. Garrido-Bailon, and M. Higes. 2007. Outcome of colonization of Apis mellifera by Nosema ceranae. Applied and Environmental Microbiology 73:6331-6338.

Martínez, J., G. Leal, and P. Conget. 2012. Nosema ceranae an emergent pathogen of Apis mellifera in Chile. Parasitology Research 111:601-607.

Meana, A., R. Martín-Hernández, and M. Higes. 2010. The reliability of spore counts to diagnose Nosema ceranae infections in honey bees. Journal of Apicultural Research 49:212-214.

OIE. 2008. Nosemosis of honey bees. OIE Terrestrial Manual. Chapter 2.2.4. Nosemosis of honey bees. World Organisation for Animal Health, Paris, France. In http://www.oie.int/fileadmin/ Home/eng/Health_standards/tahm/2.02.04_NOSEMOSIS.pdf (accessed 16 March 2013).

Potts, S.G., J.C. Biesmeijer, C. Kremen, P. Neumann, O. Schweiger, and W.E. Kunin. 2010. Global pollinator declines: trends, impacts and drivers. Trends in Ecology \& Evolution 25(6):345-353.

Reynaldi, F.J., G.H. Sguazza, M.R. Pecoraro, M.A. Tizzano, and C.M. Galosi. 2010. First report of viral infections that affect argentine honeybees. Environmental Microbiology Reports 2:749-751

Rodríguez, M., M. Vargas, M. Gerding, H. Navarro, and K. Antúnez. 2012. Viral infection and Nosema ceranae in honey bees (Apis mellifera) in Chile. Journal of Apicultural Research 51:285-287.

Tamura, K., D. Peterson, N. Peterson, G. Stecher, M. Nei, and S. Kumar. 2011. MEGA5: Molecular evolutionary genetics analysis using maximum likelihood, evolutionary distance, and maximum parsimony method. Molecular Biology and Evolution 28:27312739

Teixeira, E.W., Y. Chen, D. Message, J. Pettis, and J. Evans. 2008. Virus infections in Brazilian honey bees. Journal of Invertebrate Pathology 99:117-119.

Tentcheva, D., L. Gauthier, S. Jouve, L. Canabady-Rochelle, B. Dainat, F. Cousserans, et al. 2004. Polymerase chain reaction detection of deformed wing virus (DWV) in Apis mellifera and Varroa destructor. Apidologie 35:431-439.

vanEngelsdorp, D., and M.D. Meixner. 2010. A historical review of managed honey bee populations in Europe and the United States and the factors that may affect them. Journal of Invertebrate Pathology 103:S80-S95.

Yooa, M.-S., K.C.N. Thia, P.V. Nguyena, S.-H. Hanb, S.-H. Kwonc, and B.-S. Yoona. 2012. Rapid detection of sacbrood virus in honeybee using ultra-rapid real-time polymerase chain reaction. Journal of Virological Methods 179:195-200

Yue, C., and E. Genersch. 2005. RT-PCR analysis of Deformed wing virus in honeybees (Apis mellifera) and mites (Varroa destructor). Journal of General Virology 86:3419-3424.

Zhang, X., S.Y. He, J.D. Evans, J.S. Pettis, G.F. Yin, and Y.P. Chen. 2012. New evidence that deformed wing virus and black queen cell virus are multi-host pathogens. Journal of Invertebrate Pathology 109:156-159. 